\title{
Effects of different drying rates on the physiological quality of Coffea canephora Pierre seeds
}

\author{
Sttela Dellyzete Veiga Franco da Rosa ${ }^{1, *}$, Delacyr da Silva Brandão Júnior ${ }^{2}$, Édila Vilela de Resende Von Pinho ${ }^{3}$, André \\ Delly Veiga ${ }^{4}$ and Luiz Hildebrando de Castro e Silva ${ }^{4}$
}

${ }^{I}$ Embrapa Café, CEPE Café/DAG/UFLA, CP 37, 37200-000, Lavras, MG, Brasil; ${ }^{2}$ Universidade Federal de Diamantina, Diamantina, MG, Brasil; ${ }^{3}$ Setor de Sementes/DAG/UFLA, CP 37, Lavras, MG, Brasil; ${ }^{4}$ Setor de Sementes/DAG/UFLA, Lavras, MG, Brasil. Corresponding author: sttelaveiga@ufla.br

Received: 16/02/2005, Accepted 17/06/2005

Desiccation tolerance in seeds depends on the species, development stage and drying conditions, especially the water removal rate. Coffea seeds are considered of intermediate performance, because they tolerate relative dehydration compared to orthodox seeds and are sensitive to low temperatures. The objective of this study was to verify the effect of different drying rates on the viability and storability of Coffea canephora seeds. A complete randomized experimental design was used, in a factorial $3 \mathrm{x}$ 5 x 2 design, with three drying rates (fast, intermediate and slow), five final mean water contents after drying (51, 42, 33, 22 and $15 \%)$ and two storage temperatures $\left(10\right.$ and $\left.20^{\circ} \mathrm{C}\right)$. The germination and seed vigor assessments, using radicle protrusion, cotyledon leaf opening, seedling emergence and emergence speed index, were performed shortly after drying and after two and four months storage. It was observed that with reduction in the water content there was reduction in the germination values and seed vigor, for all the drying rates. The greatest reductions in physiological quality occurred when the seeds were dried quickly and the best results were obtained at the intermediate drying rate. There was an effect of drying rate and storage temperature on the physiological quality of the seeds, and lower germination and vigor values were observed in seeds with lower water content stored at $20^{\circ} \mathrm{C}$. C. canephora seeds were tolerant to desiccation down to $15 \%$ water content and can be stored for four months at $10^{\circ} \mathrm{C}$. A temperature of $20^{\circ} \mathrm{C}$ can be used to store C. canephora seeds, as long as the water content is not reduced to values below $22 \%$ water content.

Key words: coffee tree, desiccation tolerance, seeds, seed storage.

Efeitos de diferentes velocidades de secagem sobre a qualidade fisiológica de sementes de Coffea canephora Pierre: A tolerância à dessecação de sementes depende da espécie, do estádio de desenvolvimento e das condições de secagem, particularmente da velocidade de retirada da água. Sementes de Coffea são consideradas de comportamento intermediário, pois toleram uma relativa desidratação, comparada às ortodoxas, e são sensíveis a baixas temperaturas. Objetivou-se, neste trabalho, verificar o efeito de diferentes velocidades de secagem sobre a viabilidade e a armazenabilidade de sementes de Coffea canephora. $\mathrm{O}$ delineamento experimental foi inteiramente casualizado, em esquema fatorial $3 \times 5 \times 2$, com três velocidades de secagem (rápida, intermediária e lenta), cinco teores médios finais de água, após secagem (51, 42, 33, 22 e 15\%) e duas temperaturas de armazenamento $\left(10\right.$ e $\left.20^{\circ} \mathrm{C}\right)$. As avaliações de germinação e de vigor das sementes, pelos testes de protrusão radicular, de folhas cotiledonares, de emergência e de índice de velocidade de emergência, foram realizadas logo após a secagem, aos dois e aos quatro meses de armazenamento. Observou-se que, com a redução do teor de água, ocorreu a redução dos valores de germinação e do vigor das sementes, para todas as velocidades de secagem, sendo que as maiores reduções em qualidade fisiológica ocorreram quando as sementes foram secadas rapidamente e, os melhores resultados, na velocidade intermediária de secagem. Houve efeito da velocidade de secagem e da temperatura de armazenamento sobre a qualidade fisiológica das sementes, observando-se menores valores de germinação e de vigor em sementes com menores teores de água e armazenadas a $20^{\circ} \mathrm{C}$. Sementes de C. canephora são tolerantes à dessecação até $15 \%$ de teor de água e podem ser armazenadas por quatro meses a $10^{\circ} \mathrm{C}$. Temperatura de $20^{\circ} \mathrm{C}$ pode ser utilizada para o armazenamento de sementes de C. canephora, desde que o teor de água não seja reduzido para valores abaixo de $22 \%$ do conteúdo de água.

Palavras-chave: armazenamento, cafeeiro, tolerância à dessecação, sementes. 


\section{INTRODUCTION}

Seeds that tolerate desiccation and survive in a dehydrated state are called orthodox and those that do not tolerate dehydration, are sensitive to low temperatures and do not survive storage in a dehydrated state are called recalcitrant (Roberts, 1973). These differences in performance during storage depend on the characteristics inherent to the species, seed development stage and the conditions under which they are dried, especially the drying rate. Several authors (Farrant et al., 1985; Berjak et al., 1990; Blackman et al., 1992; Finch-Savage, 1992; Berjak et al., 1993; Pammenter et al., 1999) have reported the significant effects of drying rates on sensitivity to desiccation, isolated embryos, recalcitrant and intermediate seeds, normally expressed in terms of critical water content or critical water potential, below which significant damage is observed.

Slow drying can induce tolerance to desiccation in immature orthodox seeds or somatic embryos (Bochicchio et al., 1996; Sanhewe and Ellis, 1996; Black et al., 1999) or induce tolerance at high drying temperature in orthodox seeds (Rosa et al., 2004). Slow desiccation in orthodox seeds is an event that occurs naturally at the end of the maturation stage and in some cases is a prerequisite for germination, as observed in pea (Rogerson and Matthews, 1997) and corn seeds (Herter and Burris, 1989).

In contrast, recalcitrant seeds do not go through drying at the end of the maturation stage and apparently do not acquire tolerance to desiccation, probably because the seeds start germination shortly after maturation and at this stage events associated with germination vary among species (Farrant et al., 1993; Pammenter and Berjack, 1999). According to these authors, some seeds sensitive to dehydration can tolerate some water loss and the amount varies with the rate at which the water is removed. Indeed, it is well documented for seeds sensitive to dehydration that faster and earlier dehydration after maturation results in a lower water content to which seeds or axes can be dried before losing viability (Kundu and Kachari, 2000; Walters et al., 2001). The improved physiological quality attained by fast drying of seeds sensitive to desiccation has been attributed to the fact that these seeds remain less time at a particular hydration stage, where the defense mechanisms against desiccation damage are not efficient (Pammenter et al., 1998).

The lowest safe final water content after drying sensitive seeds, that is, below which the seeds cannot be dried without losing viability, depends on several factors such as the drying method, seeds size, development stage or maturity and the chemical nature of the main reserve material (Pritchard, 1991; Finch-Savage, 1992; Farrant et al., 1993; Tompsett, 1984, quoted by Kundu and Kachari, 2000).

Coffee seeds have been considered intermediate in terms of performance during storage (Ellis et al., 1990 and 1991; Hong and Ellis, 1995; Eira et al., 1999b), because they tolerate some dehydration compared to recalcitrant seeds and can present low-temperature sensitivity.

Data are scarce on the effects of different drying methods, with different water removal rates, on the final critical water content of coffee seeds. Thus, in this investigation, the effects of three different drying rates were studied on the moisture levels that can be reached by Coffea canephora Pierre seeds without loss of viability and that permit their safe conservation.

\section{MATERIAL AND METHODS}

The study was carried out at the Seed Analysis Laboratory at Universidade Federal de Lavras. C. canephora Pierre, Apoatã cultivar, IAC-2258 seeds were collected at the cherry stage and the pulp removed in a manual depulper. Mucilage was removed by natural fermentation in water at $30^{\circ} \mathrm{C}$ for $24 \mathrm{~h}$ and the seeds were then washed and left on paper to remove the excess superficial water before being submitted to the different drying methods. The seeds presented $50.74 \%$ water content (bu) at the start of drying.

Three drying methods were used to obtain three different drying rates: 1) drying in a thin layer in a smallscale stationary dryer, with $25 \mathrm{~m}^{3} \cdot \mathrm{min}^{-1} \cdot \mathrm{ton}^{-1}$ air flow and $30^{\circ} \mathrm{C}$ average temperature (fast drying rate); 2) drying in hermetically sealed plastic boxes, with $\pm 33 \%$ relative air humidity, obtained by forced air circulation at $20^{\circ} \mathrm{C}$ over a hygroscopic saline $\mathrm{MgCl}_{2}$ solution, according to Vertucci and Roos (1993) (intermediate drying rate); and 3) drying in the shade, at $20.3^{\circ} \mathrm{C}$ average temperature (slow drying rate). Thus the mean drying rates obtained were $1.25,0.50$ and $0.15 \% \cdot \mathrm{h}^{-1}$, in the fast, intermediate and slow dryings, respectively, calculated by the quotient between the total moisture removed and the time taken to dry.

The drying process was monitored by weighing the seeds on a $0.01 \mathrm{~g}$ precision balance and samples were removed as the drying progressed to obtain seeds with average water contents of $42 \%( \pm 0.60), 33 \%( \pm 0.60), 22 \%( \pm 0.58)$ and 15 $\%( \pm 0.30)(\mathrm{bu})$ in each drying method. A sample of seeds not submitted to drying was used with $50.7 \%$ water content.

Immediately after the drying treatments and after two and four months of storage in hermetically sealed packages 
at $20^{\circ} \mathrm{C}$ and $10^{\circ} \mathrm{C}$, the seeds were submitted to physiological quality assessments by the following tests.

Germination test: performed with four subsamples of 50 seeds per batch, distributed on paper towels, moistened with a quantity of water equivalent to 2.5 times the weight of the dry substrate and placed to germinate at $30^{\circ} \mathrm{C}$; assessment was performed 30 days after sowing, according to the Rules for Seed Analysis - RAS (Brasil, 1992), and the results were expressed in percentage.

Radicle protrusion: performed at 15 days after the start of the germination tests, when the seeds that presented radicle emission of at least $2 \mathrm{~mm}$ were counted and the results were expressed in percentage.

Open cotyledon leaves: performed about 45 days after the start of the germination test. The seedlings that presented open cotyledon leaves were counted and the results expressed in percentage.

Emergence test: performed with four subsamples of 50 seeds distributed in plastic boxes containing a mixture of soil and sand at the ratio of 2:1, maintained in a growth chamber at $30^{\circ} \mathrm{C}$; the normal emerged seedlings were counted at 60 days and results expressed in percentage.

Emergence speed index: calculated according to the formula proposed by Edmond and Drapala (1958), using the results from the daily assessments of the emergence test.

A complete randomized block design was used, with four replications in a 3 (drying rates) x 5 (final seed water content) $\mathrm{x} 2$ (storage temperatures). The means were compared by the Scott-Knott test at $5 \%$ probability, after transforming the percentage values to $\left[\left(\operatorname{arc} \operatorname{sen} X \cdot 100^{-1 / 2}\right)+0.5\right]$. The data analysis was carried out by the Sisvar program.

\section{RESULTS}

The analysis of variance of the data from the germination and seed vigor tests of the $C$. canephora seeds carried out immediately after the drying treatments showed that the effects of the drying rate on the seed physical quality was significant only for radicle protrusion. The effects of the final water content on the seeds were significant for all the variables tested, except for the percentage of open cotyledon leaves. The interaction among the factors drying rates and final seed water content was significant only for radicle protrusion. In the seed physiological quality assessments made immediately after drying, quality decreased as the water content values decreased, and the greatest reductions occurred when the seeds were dried at the highest rate and the best results occurred with the intermediate drying rate (data not shown).

After two months storage, the effects of drying rate were generally less drastic than the effects of final seed water content and storage temperature. There was statistical significance for the interaction between the final seed water content and storage temperature for all the seed quality variables analyzed and the effects of drying rate were significant only for the germination values and the emergence speed index. The interaction between storage temperature and drying rate also did not cause significant effects on the physiological quality of the seeds after two months of storage.

The results of the $C$. canephora seed physiological quality assessment, after two months storage, showed a better performance of the seeds dried at the intermediate rate and stored in hermetically sealed packages at $10^{\circ} \mathrm{C}$ (data not shown). The triple interaction among the factors drying rate, final water content and storage temperature did not have a significant effect on any of the variables analyzed. However, this fact was not detected after four months of storage, when significant triple interaction effect was observed for radicle protrusion, germination, cotyledon leaf opening and emergence.

After four months of storage all the factors presented highly significant effects for almost all the variables tested, and only seedling emergence and emergence speed index were not affected by all the factors and their interactions. Again it was detected that the drying rate was the factor that least influenced the seed physiological quality, although after four months of storage, it had a greater effect than in the previous assessment periods of the seed quality. Tables 1, 2 and 3 show the results of the partitioning of the significant interactions among the factors drying rate, final water content and storage temperature. The seeds dried at the intermediate rate and stored at $10^{\circ} \mathrm{C}$ presented the best performance after four months of storage.

Analysis of the partitioning of the effects of the final seed water content, after each drying treatment and at each storage temperature, showed that $10^{\circ} \mathrm{C}$ was the most favorable temperature for storing $C$. canephora seeds, as the water content decreased from $51 \%$ (bu) to $15 \%$ (bu). 
Table 1. Assessment results, after four months of storage, of the seed physiological quality of Coffea canephora, cultivar Apoatã IAC-2258 submitted to drying at different rates for different final water contents, in function of the drying rates and storage temperatures.

\begin{tabular}{lcccccccc}
\hline Drying rate & \multicolumn{2}{c}{$\begin{array}{c}\text { Radicle Protrusion } \\
(\%)\end{array}$} & \multicolumn{2}{c}{$\begin{array}{c}\text { Germination } \\
(\%)\end{array}$} & \multicolumn{2}{c}{$\begin{array}{c}\text { Emergency } \\
(\%)\end{array}$} & \multicolumn{2}{c}{ Emergency Velocity Index } \\
\hline \multirow{2}{*}{ Fast } & $10^{\circ} \mathrm{C}$ & $20^{\circ} \mathrm{C}$ & $10^{\circ} \mathrm{C}$ & $20^{\circ} \mathrm{C}$ & $10^{\circ} \mathrm{C}$ & $20^{\circ} \mathrm{C}$ & $10^{\circ} \mathrm{C}$ & $20^{\circ} \mathrm{C}$ \\
Intermediate & $87 \mathrm{aB}$ & $73 \mathrm{bB}$ & $86 \mathrm{aA}$ & $73 \mathrm{bB}$ & $84 \mathrm{aA}$ & $69 \mathrm{bA}$ & $34 \mathrm{aB}$ & $32 \mathrm{aA}$ \\
Slow & $92 \mathrm{aA}$ & $85 \mathrm{bA}$ & $89 \mathrm{aA}$ & $85 \mathrm{bA}$ & $85 \mathrm{aA}$ & $67 \mathrm{bA}$ & $36 \mathrm{aA}$ & $34 \mathrm{bA}$ \\
\hline
\end{tabular}

Lower cases are used for comparisons within lines and capital letters within columns.

Table 2. Assessment results, after four months of storage, of the seed physiological quality of Coffea canephora, cultivar Apoatã IAC-2258 submitted to drying at different rates for different final water contents, in function of the final drying moisture and storage temperature.

\begin{tabular}{ccccccccc}
\hline $\begin{array}{c}\text { Water } \\
\text { content } \\
(\%)\end{array}$ & $\begin{array}{c}\text { Radicle Protrusion } \\
(\%)\end{array}$ & \multicolumn{2}{c}{$\begin{array}{c}\text { Germination } \\
(\%)\end{array}$} & \multicolumn{2}{c}{$\begin{array}{c}\text { Emergency } \\
(\%)\end{array}$} & \multicolumn{2}{c}{ Emergency Velocity Index } \\
\hline 51 & $95 \mathrm{aA}$ & $97 \mathrm{aA}$ & $92 \mathrm{aA}$ & $94 \mathrm{aA}$ & $94 \mathrm{aA}$ & $90 \mathrm{aA}$ & $28 \mathrm{aA}$ & $25 \mathrm{aA}$ \\
42 & $96 \mathrm{aA}$ & $97 \mathrm{aA}$ & $94 \mathrm{aA}$ & $96 \mathrm{aA}$ & $91 \mathrm{aA}$ & $94 \mathrm{aA}$ & $34 \mathrm{aB}$ & $29 \mathrm{bB}$ \\
33 & $86 \mathrm{bB}$ & $92 \mathrm{aB}$ & $84 \mathrm{bB}$ & $91 \mathrm{aA}$ & $85 \mathrm{aB}$ & $86 \mathrm{aB}$ & $34 \mathrm{aB}$ & $33 \mathrm{aC}$ \\
22 & $84 \mathrm{aB}$ & $56 \mathrm{bC}$ & $85 \mathrm{aB}$ & $54 \mathrm{bB}$ & $84 \mathrm{aC}$ & $51 \mathrm{bC}$ & $36 \mathrm{aB}$ & $37 \mathrm{aD}$ \\
15 & $84 \mathrm{aB}$ & $31 \mathrm{bD}$ & $81 \mathrm{aB}$ & $21 \mathrm{bC}$ & $69 \mathrm{aC}$ & $18 \mathrm{bD}$ & $39 \mathrm{aC}$ & $40 \mathrm{aE}$ \\
\hline
\end{tabular}

Lower cases are used for comparisons within lines and capital letters within columns.

Table 3. Assessment results, after four months of storage, of the seed physiological quality of Coffea canephora, cultivar Apoatã IAC-2258 submitted to drying at different rates for different final water contents, in function of the final drying moisture and drying rates.

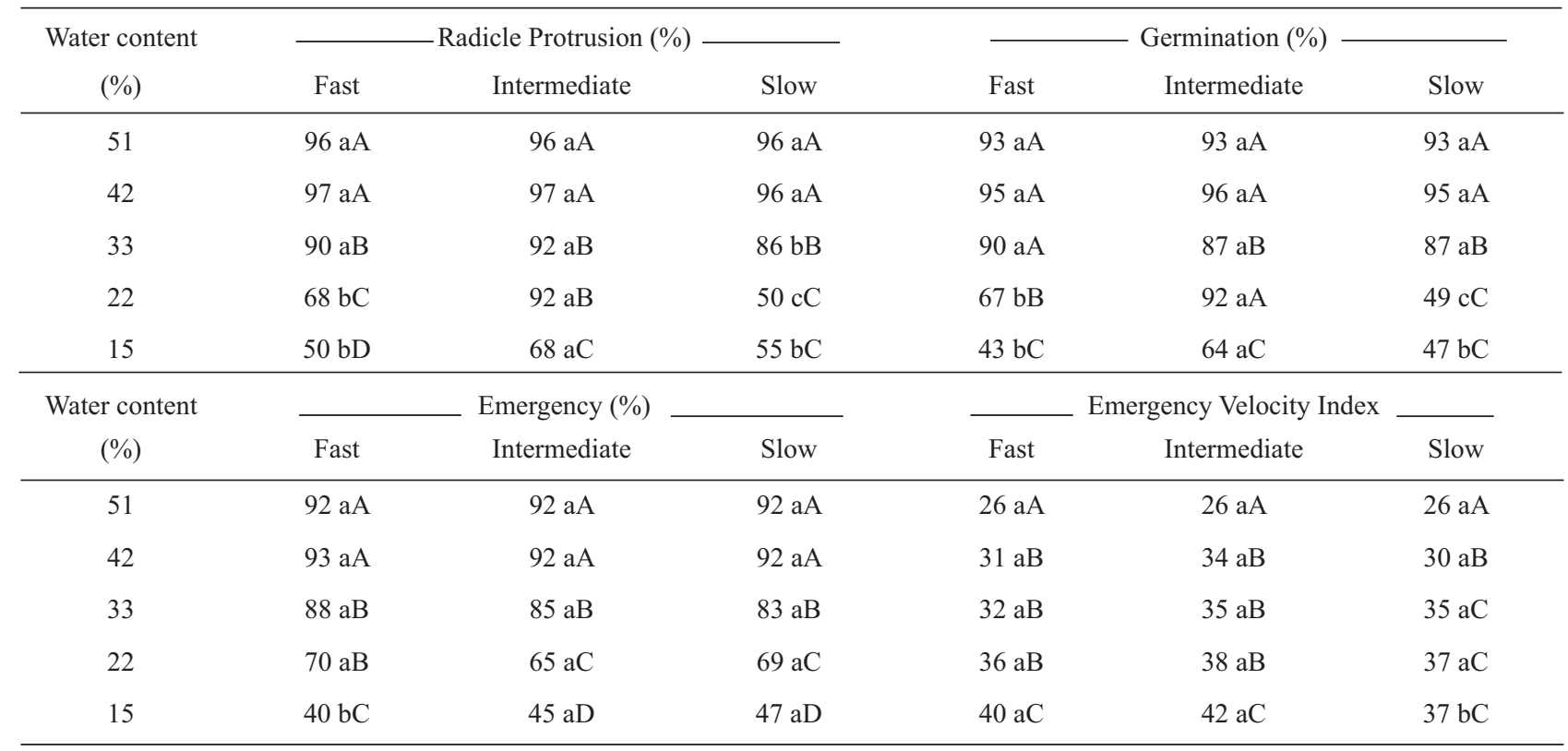

Lower cases are used for comparisons within lines and capital letters within columns. 
Generally, the $51 \%(\mathrm{bu})$ to $15 \%(\mathrm{bu})$ moisture range and both temperatures, 10 and $20^{\circ} \mathrm{C}$, were favorable for seed storage. However, below $22 \%$ moisture content greater germination and vigor values were observed in $C$. canephora seeds when stored at $10^{\circ} \mathrm{C}$, and the effect of $20^{\circ} \mathrm{C}$ storage temperature in this moisture range was detrimental to the seeds stored for four months.

Regarding the partitioning of the effect of seed water content within each drying rate, it was observed that as the seed water content decreased, the physiological quality of the seeds decreased, for all the drying rates tested. However, in spite of this reduction in the seed quality due to reduction in water content, a better physiological performance was observed in the seeds at the intermediate drying rate. On the other hand, it was observed that at the slow drying rate the seeds presented poor physiological performance below the 33 and $22 \%$ final moisture content.

Figures 1 and 2 show the surface response of the germination and radicle protrusion variables of the $C$. canephora seeds after four months of storage, dried at the intermediate rate, in function of the storage temperature and a final seed water content. There was a significant effect of the interaction among the factors seed water content and storage temperature, highlighting the more favorable effect at $10^{\circ} \mathrm{C}$, both for radicle protrusion and germination. The surface response clearly shows the worse physiological performance of the seeds with lower water content, when stored at $20^{\circ} \mathrm{C}$ thus showing that $10^{\circ} \mathrm{C}$ is the most favorable temperature for $C$. canephora seed stored in all the water content ranges studied.

\section{DISCUSSION}

According to the proposal by Roberts (1973), seeds can be classified as orthodox and recalcitrant. Orthodox seeds can be dried to low water content without suffering damage, to moisture corresponding to water potential below -350 Mpa (Roberts and Ellis, 1989), and within a wide range of environmental conditions, their longevity increases with the decrease in the relative humidity and storage temperature in a quantifiable and predictable way, defined by the viability equation (Ellis and Roberts, 1980). According to Ellis et al. (1989), the water potential of $-350 \mathrm{Mpa}$ is the limit for the negative logarithm relationships between longevity and water content. Recalcitrant seeds, on the other hand, cannot survive below a relatively high water content, and even at this high water content level, they present comparatively short longevity; furthermore, many species with recalcitrant performance are sensitive to cold, to temperatures below $15^{\circ} \mathrm{C}$ (King and Roberts, 1979). But in our studies the $C$. canephora seeds presented tolerance to desiccation down to $15 \%$ water content and withstood storage at $10^{\circ} \mathrm{C}$.

It is well documented in the literature that Coffea seeds clearly do not fit in the seed classification proposed by Roberts (1973), as orthodox and recalcitrant, regarding their performance during storage. Ellis et al. (1990, 1991) classified Coffea arabica seeds as intermediate, because they survived desiccation at approximately $10 \%$ (bu) water content and 12 months of storage under hermetic storage conditions,

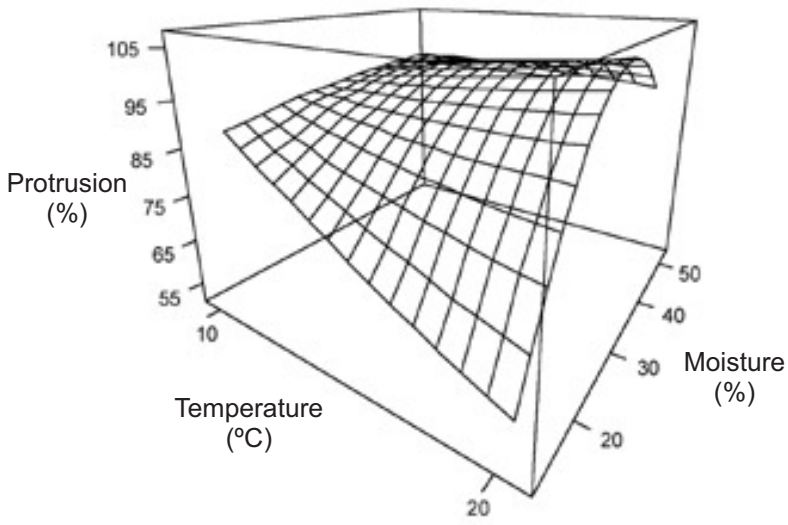

Adjusted model: $\mathrm{Y}=180.97-9.952 \mathrm{~T}-1.312 \mathrm{U}+0.0182 \mathrm{~T} 2 \mathrm{U}-0069 \mathrm{U} 2 \mathrm{~T}+0.0651 \mathrm{U} 2$ $\left(R^{2}=77.26 \%\right)$

Figure 1. Surface response of the variable radicle protrusion, after four months of storage, for the intermediate drying rate, in function of the final moisture content and storage temperature in seeds of Coffea canephora, cultivar Apoatã IAC-2258.

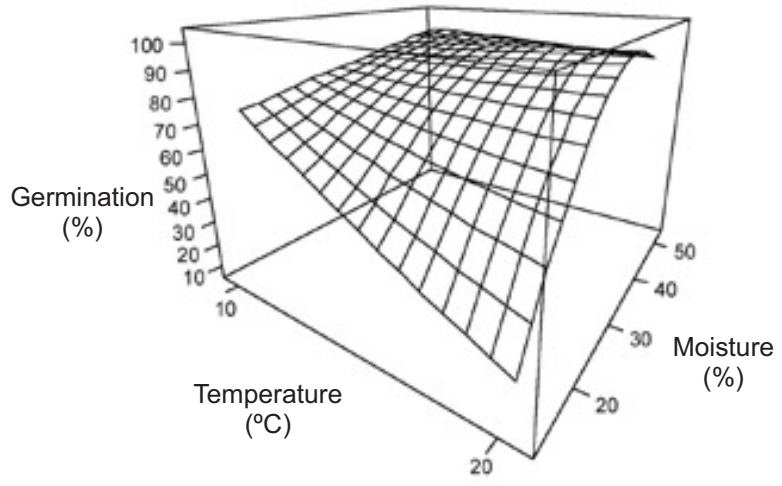

Adjusted model: $\mathrm{Y}=222.962-15.728 \mathrm{~T}-2.064 \mathrm{U}+0.0979 \mathrm{U} 2+0.0267 \mathrm{~T} 2 \mathrm{U}-0.0098 \mathrm{U} 2 \mathrm{~T}$ (R2=94.39\%)

Figure 2. Surface response of the germination variable, after four months of storage, for the intermediate drying rate, in function of final water contents, storage temperature, in seeds of Coffea canephora, cultivar Apoatã IAC-2258. 
but deteriorated more quickly at low temperatures or with a low water content. According to the authors, C. arabica seeds survive desiccation to between 7.2 to $11.3 \%$ (bu) that corresponds to water potentials between $-90 \mathrm{Mpa}$ and -150Mpa. Sun and Liang (2001) demonstrated that, among several species sensitive to desiccation, the $C$. arabica seeds were classified as the most tolerant, and could reach water potential levels of approximately $-73 \mathrm{Mpa}$ (relative humidity close to $58 \%$ ). The authors did not mention the water content values corresponding to this water potential, but according to Eira et al. (1999), C. arabica seeds in this relative moisture range register water contents close to $10 \%$ (bu).

In studies carried out by Eira et al. (1999b), the intermediate performance between orthodox and recalcitrant Coffea seeds, suggested by several authors, was confirmed. According to these authors, $C$. arabica and C. canephora seeds present the same critical level for water content $\left(0.10 \mathrm{~kg}^{\mathrm{kg}} \mathrm{kg}^{-1}\right)$ and high germination percentage when stored at $15^{\circ} \mathrm{C}$. Hong and Ellis (1995) have already confirmed the intermediate performance of $C$. canephora seeds. These authors worked with the $C$. canephora species cultivar Robusta, and $C$. liberica, cv. Libérica, and concluded that Libérica seeds have recalcitrant performance, but the Robusta seeds performed in the same way as $C$. arabica seeds reported in previous studies (Ellis et al., 1990, 1991). The C. canephora seeds, in studies by Hong and Ellis (1995), although they survived a certain minimum water content, did not tolerate desiccation to moisture levels withstood by orthodox seeds and also did not show a negative relationship between the survival periods and environmental temperature. The authors suggested that C. canephora seeds should be stored with 13 to $15 \%$ water content, at 10 to $15^{\circ} \mathrm{C}$, for medium-term storage, a fact also confirmed in the present study.

When water is removed from the cells of organisms sensitive to dehydration, two main facts can explain the damage caused, according to Walters et al. (2001), the damage that results from mechanical stresses that disturb the structural organelles at high moisture levels $(>-5 \mathrm{Mpa})$ and those that damage macromolecular structures after more extreme desiccation. According to the authors, more recent research has highlighted damage to the cell metabolic activity at an intermediate moisture level. These cells may continue to respire, but cannot remove toxic metabolic products that are accumulated. This metabolic disorder that occurs in partially dehydrated cells can also cause death to cells kept partially hydrated for a certain period which is the basis of the accelerated aging test (Delouche and Baskin,
1973); the seeds lose viability when they are kept at a water content where respiration is possible ( -15 to $-5 \mathrm{Mpa})$, but the repair processes are not efficient (Vertucci and Farrant, 1995). According to Walters et al. (2001), this metabolic disorder can contribute to damage in seeds that are stored wet or sensitive seeds that are dried slowly, because they are maintained at a critical level of moisture for a long period of time.

Generally, according to the results presented here, slow drying of $C$. canephora seeds was not the method that resulted in the greatest seed germination and vigor values after four months of storage. Slow drying of orthodox seeds allows them to go to a more advanced stage in the maturation process, where the seeds are more tolerant to desiccation (Hong and Ellis, 1997), but slow drying of sensitive seeds can permit germination and therefore allows the seeds to pass to stages more sensitive to desiccation (Seranatna and McKersie, 1983).

In the present study, the C. canephora seeds, cultivar Apoatã, dried at an intermediate rate to $15 \%$ moisture content, presented good physiological performance after four months of storage in hermetically sealed packets at $10^{\circ} \mathrm{C}$, confirming results obtained for the same species by Hong and Ellis (1995). There is an important interaction between the final seed water content and the storage temperature, and in the 50 to $15 \%$ water content range the seeds can be stored at $10^{\circ} \mathrm{C}$, with little reduction in their quality. However, the temperature $20^{\circ} \mathrm{C}$ can be used to store C. canephora seeds, as long as the seed water content is not reduced below $22 \%$.

It should be emphasized that as the water content decreased in the $C$. canephora seeds the germination and vigor values decreased during storage, for all the drying rates and temperatures tested. Therefore, according to the results obtained in this investigation, C. canephora seeds should, preferentially and whenever necessary, be dried at an intermediate rate, since slow drying, a practice normally recommended in coffee tree seed production, was shown to be more harmful than the other rates tested. This probably occurs because, during drying, the seeds remained at an intermediate hydration level for a period of time that permitted respiration and production of toxic substances but did not permit the defense mechanisms to act.

\section{REFERENCES}

Berjak P, Farrant JM, Mycock DJ, Pammenter NW (1990) Recalcitrant (homoiohydrous) seeds: the enigma of their desiccation-sensitivity. Seed Sci. Technol. 18:297-310. 
Berjak P, Vertucci CW, Pammenter NW (1993) Effects of developmental status and dehydration rate on characteristics of water and desiccation-sensitivity in recalcitrant seeds of Camellia sinensis. Seed Sci. Res. 3:155-166.

Black M, Corbineau F, Gee H, Côme D (1999) Water content, raffinose and dehydrins in the induction of desiccation tolerance in immature wheat embryos. Plant Physiol. 120: 463-471.

Blackman SA, Obendorf RL, Leopold AC (1992) Maturation proteins and sugars in desiccation tolerance of developing soybean seeds. Plant Physiol. 100:225-230.

Bochicchio A, Vernieri P, Puliga S, Murelli C, Vazzana C (1996) Desiccation tolerance in immature embryos of maize: sucrose, raffinose and the aba-sucrose relation. Proceedings of the Fifth International Workshop on Seeds: basic and applied aspects of seed biology, University of Reading, UK, 10-15 September, 1995. pp.1-12.

Brasil (1992) Ministério da Agricultura e Reforma Agrária. Regras para análise de sementes. Brasília: SNDA/DNDV/ CLAV, 1992. 365p.

Delouche JC, Baskin CC (1973) Accelerated aging techniques for predicting the relative storability of seed lots. Seed Sci. Technol. 1:427-452.

Edmond JB, Drapala WS (1958) The effects of temperature, sand and acerone on germination of okra seed. Proc. Am. Soc. Hortic. Sci. 71:428-434.

Eira MTS, Walters C, Caldas LS (1999) Water sorption properties in Coffea spp. seeds and embryos. Seed Sci. Res. 9:321-330.

Eira MTS, Walters C, Caldas LS, Fazuoli LC, Sampaio JB, Dias MCLL (1999b) Tolerance of coffea spp. seeds to desiccation and low temperature. Rev. Bras. Fisiol. Veg. 11:97-105.

Ellis RH, Roberts EH (1980) Improved equations for the prediction of seed longevity. Ann. Bot. 45-1330.

Ellis RH, Hong TD, Roberts EH, Tao KL (1990) Low moisture content limits to relations between seed longevity and moisture. Ann. Bot. 65:493-504.

Ellis RH, Hong TD, Roberts EH (1990) An intermediate category of seed storage behavior? I. Coffee. J. Exp. Bot. 41:1167-1174.

Ellis RH, Hong TD, Roberts EH (1991) An intermediate category of seed storage behavior? II. Effects of provenance, immaturity, and imbibition on desiccation-tolerance in coffee. J. Exp. Bot. 42:653-657.

Farrant JM, Berjak P, Pammenter NW (1985) The effect os drying rate on viability retention of recalcitrant propagules of Avicennia marina. South Afr. J. Bot. 51:432-438.

Farrant JM, Pammenter NW, Berjak P (1993) Seed development in relation to desiccation tolerance: a comparision between desiccation-sensitive (recalcitrant) seeds of Avicennia marina and desiccation-tolerant types. Seed Sci. Res. 3:1-13.

Finch-Savage WE (1992) Seed development in the recalcitrant species Quercus robur L.: germinability and desiccation tolerance. Seed Sci. Res. 2:17-22.

Herter U, Burris JS (1989) Preconditioning reduces the susceptibility to drying injury in corn seed. Can. J. Plant Sci. 69:775-789.

Hong TD, Ellis RH (1997) The effect of the initial rate of drying on the subsequent ability of immature seeds of
Norway maple (Acer platanoides L.) to survive rapid desiccation. Seed Sci. Res. 7:7-45.

Hong TD, Ellis RH (1995) Interspecific variation in seed storage behaviour within two genera - Coffea e Citrus. Seed Sci. Technol. 23:165-181.

King MW, Roberts EH (1979) The storage of recalcitrant seeds: achievements and possible approaches. Rome: IBPGR.

Kundu M, Kachari J (2000) Desiccation sensitivity and recalcitrant behavior of seeds of Aquilaria agallocha Roxb. Seed Sci. Technol. 28:755-760.

Pammenter NW, Berjak P (1999) A review of recalcitrant seed physiology in relation to desiccation-tolerance mechanisms. Seed Sci. Res. 9:13-37.

Pammenter NW, Berjak P, Walters C (1999) The effect of drying rate and processes leading to viability loss in recalcitrant seeds. In: Marzalina M, Khoo KC, Jayanthi N, Tsan FY, Krishnapillay B (eds), IUFRO Seed Symposium 1998, Recalcitrant Seeds, pp.14-24. Kuala Lampur, Forest Research Institute Malaysia.

Pammenter NW, Greggains V, Kioko JI, Wesley-Smith J, Berjak P, Finch-Savage WE (1998) Effects of differential drying rates on viability retention of recalcitrant seeds of Ekerbergia capensis. Seed Sci. Res. 8:463-471.

Pritchard HW (1991) Water potential and embryonic axis viability in recalcitrant seeds of Quercus rubra. Ann. Bot. 67:43-49.

Roberts EH (1973) Predicting the storage life of seeds. Seed Sci. Technol. 1:499-514.

Roberts EH, Ellis RH (1989) Water and seed survival. Ann. Bot. 63:39-52.

Rogerson NE, Matthews S (1977) Respiratory and carbohydrate changes in developing pea (Pisum sativum L.) seeds in relation to their ability to withstand desiccation. J. Exp. Bot. 28:304-313.

Rosa SDVF, Von Pinho EVR, Vieira MGG, Veiga RD (2004) Indução de tolerância à alta temperatura de secagem em sementes de milho por meio de pré-condicionamento à baixa temperatura. Rev. Bras. Milho Sorgo 3:290-310.

Sanhewe AJ, Ellis RH (1996) Seed development and maturation in Phaseolus vulgaris. I. Ability to germinate and to tolerate desiccation. J. Exp. Bot. 47:949-958.

Senaratna T, Mckersie BD (1983) Dehydration injury in germinating soybean (Glycine max L. Merr.) seeds. Plant Physiol. 72:620-624.

Sun WQ, Liang Y (2001) Discrete levels of desiccation sensitivity in various seeds as determined by the equilibrium dehydration method. Seed Sci. Res. 11:317-323.

Vertucci CW, Farrant JM (1995) Acquisition and loss of desiccation tolerance. In: Kigel J, Galili G (eds), Seed Development and Germination, pp.237-271. Marcel Dekker Inc. New York.

Vertucci CW, Roos EE (1993) Theoretical basis of protocols for seed storage. II. The influence of temperature on optimal moisture levels. Seed Sci. Res. 3:201-213.

Walters C, Pammenter NM, Berjak P, Crane J (2001) Desiccation damage, accelerated ageing and respiration in desiccation tolerant and sensitive seeds. Seed Sci. Res. $11: 135-148$ 